anales de psicología, 2018, vol. 34, $\mathrm{n}^{\circ} 1$ (january), 101-107 http://dx.doi.org/10.6018/analesps.34.1.237231
(C) Copyright 2018: Editum. Servicio de Publicaciones de la Universidad de Murcia. Murcia (Spain) ISSN print edition: 0212-9728. ISSN web edition (http://revistas.um.es/analesps): 1695-2294

\title{
The corporate social responsibility policies for the inclusion of people with disabilities as predictors of employees' identification, commitment and absenteeism
}

\author{
Francisco J. Perez, Marina Romeo*, and Montserrat Yepes-Baldó
}

University of Barcelona (Spain).

\begin{abstract}
Título: Las políticas de responsabilidad social corporativa para la inclusión de las personas con discapacidad como predictores de identificación, compromiso y absentismo de los empleados.

Resumen: Pocos estudios han analizado el efecto en los empleados de las políticas de Responsabilidad Social Corporativa (RSC) orientadas a la inclusión de las personas con discapacidades. La presente investigación examina el grado en que las percepciones de los empleados sobre dichas políticas están relacionadas con la identificación y el compromiso con la organización, y con el absentismo. Se administró un cuestionario a 104 empleados (tasa de participación: 41,1\%). Se realizaron correlaciones, pruebas de varianza del método común, y regresiones lineales. Si bien el efecto de las políticas de RSC orientadas hacia el entorno de la organización han sido las más estudiadas, nuestra investigación pone de relieve el impacto de las políticas internas para la inclusión de las personas con discapacidad sobre el compromiso y la identificación de todos los empleados, las personas con y sin discapacidad, pero no así con el absentismo. Los resultados obtenidos contribuyen significativamente al diseño de estrategias que faciliten y mejoren la normalización del colectivo de personas con discapacidad en el mercado de trabajo, contribuyendo a su inserción laboral.

Palabras clave: Absentismo; Compromiso; Políticas de responsabilidad social corporativa; Identificación; Personas con discapacidades.
\end{abstract}

\section{Introduction}

A concern of professionals and researchers in the area of social and organizational psychology is promoting autonomy, social and labor inclusion and quality of life of people with disability (Alcover de la Hera \& Pérez Torres, 2011). Nevertheless, the international regulations to increase the employment rate of people with disabilities have not obtained the expected results (Wiggett-Barnard \& Swartz, 2012). In this sense, the International Labour Office (International Labour Office, ILO, 2015) points out that promoting the employment of people with disabilities requires strategic design of organizational internal and external policies, such as disability awareness training for management and co-workers or business-to-business relationships with entrepreneurs with disabilities. These policies are related to all those guidelines, rules and procedures established by organization management and aimed at achieving previously planned objectives (David, 2010).

For the European Commission, policies related to the inclusion of people with disabilities, among others (human rights, labor practices and employment, environmental issues and the fight against fraud and corruption, local community participation and development, and the interests of consum-

* Correspondence address [Dirección para correspondencia]:

PhD. Marina Romeo. Department of Social Psychology. University of Barcelona. Passeig de la Vall d'Hebron, 171. 08035 Barcelona (Spain). Email: mromeo@ub.edu

PsicoSAO. Research Group in Social, Environmental and Organizational Psychology (2014 SGR 992).
Abstract: Few studies have explored the effect on employees of corporate social responsibility (CSR) policies focused on the inclusion of people with disabilities. The present research examines the extent to which employees' perceptions of CSR policies aimed at the employment of disabled people are related to organizational identification, commitment, and absenteeism. A questionnaire was administered to 104 employees (participation rate: $41.1 \%)$. Correlations and common method variance tests, and linear regressions were performed. Only the internal-focus policies have an effect on employees' identification and commitment, although the effect of external-focus policies have been more deeply studied. There were no significant results related to absenteeism. Our research highlights the impact of internal-focus policies for the inclusion of people with disabilities in the commitment and identification of all employees, those with and without disabilities. The results also contribute significantly to the design of strategies that facilitate and enhance the normalization of these employees in the labor market, helping practitioners to target these companies as future employers of people with disabilities.

Keywords: Absenteeism; Commitment; Corporate social responsibility policies; Identification; People with disabilities.

ers, disclosure of non-financial information and volunteerism among employees), are conceived as expressions of Corporate Social Responsibility (CSR). Those companies with higher implementation and development of these CSR policies can obtain

positive direct and indirect effects. Positive direct results may for example derive from a better working environment, which leads to a more committed and productive workforce, or from efficient use of natural resources. In addition, indirect effects result from the growing attention of consumers and investors, which will increase their opportunities on the markets (European Commission, 2001, p.7).

Following Dahlsrud (2008), it is possible to consider that those direct and indirect effects are related to external- and internal-focus policies. Specifically, external-focus policies are the set of practices oriented towards the local community, business partners and suppliers, customers, public authorities and non-governmental organizations, protecting the environment and fostering philanthropy and volunteerism. On the other hand, internal-focus policies are those directly related to employees' physical and psychological environment, health and welfare, training, participation in business, equal opportunities and work-life balance (Al-bdour, Nasruddin, \& Lin, 2010; Turker, 2009).

The effects on external stakeholders of the external-focus policies have been deeply studied (Aguinis \& Glavas, 2012; Branco \& Rodrigues, 2006; Wang, Tong, Takeuchi, \& George, 2016). Nevertheless a comprehensive overview of both focuses considers that corporate social responsibility (CSR) is oriented towards integrating the interests of all indi- 
viduals or stakeholders in the policies and actions of the organization. In this sense, the definition proposed by the European Commission (2011) views CSR as encompassing external- and internal-focus policies.

\section{Corporate Social Responsibility and effectiveness}

Several authors suggest that the implementation of corporate social responsibility (CSR) policies could generate competitive advantages that enhance organizational effectiveness (Aharon, Lior, Yaki, \& Gal, 2011; Ali, Rehman, Ali, Yousaf, \& Zia, 2010; Birth, Illia, Lurati, \& Zamparini, 2009; Brammer, Millington, \& Rayton, 2007; Galbreath, 2010; Kim, Lee, Lee, \& Kim, 2010; Pinillos, 2009; Skudiene \& Auruskeviciene, 2012; Turker, 2009; Villafañé, 2009; Vitaliano, 2010). However, it is interesting to highlight the limited number of studies that have had an impact on employees (Rodrigo \& Arenas, 2008). These authors point out that

this is especially surprising because attraction of talent, loyalty to a firm, and motivation have been used to explain why CSR can be a source of competitive advantage to a firm (Branco \& Rodrigues, 2006). Even less attention has been devoted to the differences among employees in relation to CSR, presupposing that this group's expectations, views, and attitudes were homogeneous (Rodrigo \& Arenas, 2008, p. 266).

The effect of CSR on employees has been analyzed in terms of effectiveness regarding both outcomes in people in general and the results provided by individuals in organizations (Quijano, Navarro, Yepes, Berger, \& Romeo, 2008). Among the findings related to results of individuals in organizations, several studies have analyzed the relationship between the deployment of corporate social responsibility policies, organizational commitment (Ali, Rehman, Ali, Yousaf, \& Zia; 2010, Brammer, Millington, \& Rayton, 2007; Turker, 2009), identification (Kim, Lee, Lee, \& Kim, 2010), and absenteeism (National Disability Coordination Officer Program, nd).

All these studies conceptualize CSR as an independent variable in regression models, and distinguish the effect of internal and external policies. In this sense, the above mentioned studies confirm that both internal and external CSR policies have a positive effect on employees' commitment (Ali, Rehman, Ali, Yousaf, \& Zia; 2010, Brammer, Millington, \& Rayton, 2007; Turker, 2009).

Furthermore, Ali et al. (2010) and the National Disability Coordination Officer Program (nd) indicate that CSR has an effect on organizational effectiveness (in terms of reduced absenteeism and financial results), although in some cases commitment mediates this relationship (Ali et al., 2010).

Regarding identification, Kim et al. (2010) noted that only internal focus CSR policies have an impact on the degree of overlap between an employee's self-concept and his or her perception of the Company. Furthermore, identification facilitates employees' organizational commitment.

Hence, the present research analyzes the extent to which employees' perceptions of corporate social responsibility policies aimed at the inclusion of people with disabilities are positively related to organizational identification and commitment, and negatively related to absenteeism.

\section{Method}

\section{Participants and data collection}

Despite the global crisis, Catalonia is considered one of the most dynamic European regions in the biotechnology and biomedicine sector (Ernst \& Young, \& Biocat, 2011). For this reason, data was collected at one of the most important companies in the biotechnology sector in this region between December 2013 and January 2014. The company has expanded over the last five years, both in terms of the number of employees and economic growth $(100 \%$ increase in income per employee), as reported by the Iberian Balance Analysis System (Sistema de Análisis de Balances Ibéricos $\mathrm{SABI}$ ). The company fulfills the Spanish Law (Real Decreto $1 / 2013$ ), employing a ratio of $2 \%$ of employees with disabilities and adapting its facilities and workplaces. Additionally, the company hires the services of gardening and maintenance of a company that mainly employ people with disabilities.

The employees were asked to participate in order to analyze their perception of policies aimed at inclusion of people with disabilities. They completed an online questionnaire. Participants were informed that their confidentiality was ensured, anonymity would be maintained, and of their right to withdraw from the study at any time without negative impact. Participation was voluntary.

A total of 104 employees participated, making up 41.1\% of the company staff. A greater number of participants were women $(66.3 \%)$ and had university degrees (54.8\%). The mean age was 38.01 years $(S D=8.9)$ and mean tenure 11.2 years $(S D=10.5)$. Almost all employees had permanent contracts $(95.2 \%)$ and worked full-time (98.1\%), and well over half held technical positions $(62.5 \%)$ (Table 1$)$.

Table 1. Socio-demographic data.

\begin{tabular}{lc}
\hline Variables & Percentage \\
\hline Gender: & \\
Male & $33.7 \%$ \\
Female & $66.3 \%$ \\
Work relationship: & \\
Permanent & $95.2 \%$ \\
Schedule: & \\
Full time & $98.1 \%$ \\
Position: & \\
Manager & $10.6 \%$ \\
Specialist & $20.2 \%$ \\
Technical & $62.5 \%$ \\
Unqualified & $1 \%$ \\
Other & $5.8 \%$ \\
Level of studies: & \\
University & $54.8 \%$ \\
Secondary & $44.3 \%$ \\
Primary & $1 \%$ \\
\hline
\end{tabular}




\section{Instruments and variables}

The questionnaire consisted of 30 items where dichotomous and categorized questions were combined. The instruments included were a validated questionnaire and another developed ad-hoc. The validated questionnaire was used to measure the variables of identification and commitment (Identification-Commitment Inventory - ICI) (Quijano, Navarro, Cornejo, 2000; Romeo, Yepes, Berger, Guàrdia, \& Castro, 2011; Romeo, Berger, Yepes-Baldó, \& GuardiaOlmos, 2011). The ad-hoc questionnaires explored perception of deployment and importance of internal and external-focus policies, and absenteeism. The characteristics of the instruments are listed below:

a) Perception of deployment of corporate social responsibility policies aimed at inclusion of people with disabilities (CSR-D) (five items): guidelines, rules and procedures established in order to support efforts to achieve the planned objectives (David, 2010). Given that this scale was created ad-hoc for this research, we checked its internal consistency and construct validity using Cronbach's alpha and exploratory factor analysis (EFA), respectively. Cronbach's alpha was .896 . The EFA identified two factors $(68.9 \%$ of explained variance - EV), which corresponded to internal policies (three items, $46.8 \% \mathrm{EV}$ ) and external policies (two items, 22.1\% EV). An example of an item from the scale of internal policies is "Are there corporate policies that define the commitment and company goals on inclusion of people with disabilities?" An example of an item referring to external policies is "Does the Company collaborate with the local community and associations of people with disabilities to raise awareness and promote the inclusion of people with disabilities in the labor market?"

b) Individual Effectiveness (16 items): Results analyzed in individuals were identification and commitment, and absenteeism.

Identification and commitment. There exists a relation between commitment and identification, although each one is operatively different (Quijano, Navarro, Cornejo, 2000; Romeo, Yepes, Berger, Guàrdia, \& Castro, 2011; Romeo, Berger, Yepes-Baldó, \& Guardia-Olmos, 2011).

- Commitment constitutes the psychological link that employees develop towards the organization (Quijano, Navarro, Cornejo, 2000). It includes four dimensions: value commitment (strongest link focused on recognition of common goals and values between individual and organization), affective commitment (affective link between employee and organization resulting from affiliation needs), exchange commitment (based on more or less satisfactory retributions/compensations received from the organization), and need commitment (weakest link focused only on the maintenance of the job as a way of survival).

- Identification is understood as awareness of member- ship, self-esteem for being an organizational member and desire to stay in the organization.

The Identification-Commitment Inventory (Quijano, Navarro, \& Cornejo, 2000; Romeo, Yepes, Berger, Guàrdia, \& Castro, 2011; Romeo, Berger, Yepes-Baldó, \& GuardiaOlmos, 2011) has 14 items, six correspond to identification. Cronbach's alpha for the full scale was .94 (Romeo, Yepes, Berger, Guàrdia, \& Castro, 2011). The ICI model fit is verified with root mean square error of approximation (RMSEA) $=.028$, root mean squares residual $(\mathrm{RMSR})=.041$, goodness-of-fit index $(\mathrm{GFI})=.983$, adjusted goodness-of-fit in$\operatorname{dex}(\mathrm{AGFI})=.977$, and comparative fit index $(\mathrm{CFI})=.994$ (Romeo, Yepes, Berger, Guàrdia, \& Castro, 2011).

An example of an item of identification is "I feel part of this organization". The commitment scale consisted of eight items, two per subdomain. Cronbach's alpha for the full scale was .91 , and .87 for value commitment ("I feel that there is a great similarity between my personal values and those of this organization"), .88 for affective commitment ("The success of my organization is my success"), .89 for exchange commitment ("An important reason why I continue working in this organization is that I do not feel that other organizations can offer me better compensation"), and .91 for need commitment ("I would not recommend working in this organization to any family member or friend") (Romeo, Berger, Yepes-Baldó, \& Guardia-Olmos, 2011).

Absenteeism: We analyzed the levels of absenteeism among employees, identified by several authors as an indicator of effectiveness (Campbell, 1997; International Organization for Standardization, ISO, 2010; Quijano, Navarro, Yepes, Berger, \& Romeo, 2008). Two questions about absence caused by contingencies other than accidents in the last three months were included.

We also included the following control variables:

a) Some of the socio-demographic data have been included as control variable for theoretical reasons (Brammer et al., 2007; Skudiene \& Auruskeviciene, 2012; Turker, 2009) (four items): Gender, age, organizational tenure and position.

b) Importance attributed to internal- and external-focus policies aimed at the employment of people with disabilities (five items): It was considered important to minimize any bias associated with the perceived importance of policies for the employment of people with disabilities. Participants were asked to grade the degree of importance of internal- and external-focus policies on a five-point Likert scale $(1=$ Not important; $5=$ Very important). An example of an item related to the importance of internalfocus policies-focus is "What level of importance do you attribute to the existence of corporate policies that define the commitment and company goals in the field of labor inclusion of people with disabilities?", and regarding the importance of external-focus policies: "What level of importance do you attribute to collaboration with the local community and associations of people with disabilities for raising awareness and promoting the inclusion of people with disabilities in the labor market?". 


\section{Data analysis}

Data analysis was performed using SPSS 21. Correlations were sought between the control variables, the independent variables and the dependent variables. Subsequently, linear regression analyses including those variables with significant correlations were performed. The first step contained a control-only model, including gender, organizational tenure, position, and importance ratings of internal and external-focus policies. The second step contained the main analyses, and included the effect of employees' perceptions of policies deployment on identification and commitment.

Harman's single-factor test (Podsakoff, MacKenzie, Lee, \& Podsakoff, 2003) was used to analyze whether there is any presence of common method bias in our data, due to the fact that we are only using questionnaires to collect data. The principal component analysis of all the variables produced four distinct factors. The four factors accounted for $67.02 \%$ of the total variance but the first factor did not account for a majority of the variance $(9.94 \%)$. Thus, it could be claimed that the common method bias was not a serious threat.

\section{Results}

Between $44.2 \%$ and $81.7 \%$ of employees did not know the extent of deployment of the policies analyzed. The policies perceived as being the most deployed are the external-focus policies. Specifically, the percentage of employees who claimed to know that their organization was working with the local community and had strategic partnerships with specialized institutions was $35.6 \%$ and $50 \%$ respectively (Table 2).

Table 2. Perceptions on policy deployment.

\begin{tabular}{|c|c|c|c|}
\hline Dimension & Item & No & Don't know \\
\hline \multirow{3}{*}{$\begin{array}{l}\text { Internal-focus } \\
\text { policies }\end{array}$} & Is the communication plan adapted to the specific needs of employees? & $16(15.4 \%)$ & $48(46.2 \%)$ \\
\hline & $\begin{array}{l}\text { Are there corporate policies that define the commitment to and company goals aimed } 14(13.5 \%) \\
\text { at labor inclusion of people with disabilities? }\end{array}$ & $17(16.3 \%)$ & $73(70.2 \%)$ \\
\hline & $\begin{array}{l}\text { Is there a strategic plan involving the main stakeholders of the company aimed at } 6(5.8 \%) \\
\text { normalizing disability in the business and work environment? }\end{array}$ & $13(12.5 \%)$ & $85(81.7 \%)$ \\
\hline \multirow{2}{*}{$\begin{array}{l}\text { External-focus } \\
\text { policies }\end{array}$} & $\begin{array}{l}\text { Is the organization working with the local community and associations to raise } \\
\text { awareness and promote the inclusion and inclusion of people with disabilities in the } \mathbf{3 7}(\mathbf{3 5 . 6} \%) \\
\text { labor market? }\end{array}$ & $12(11.5 \%)$ & $55(52.9 \%)$ \\
\hline & $\begin{array}{l}\text { Has the organization developed partnerships with specialist organizations in order to } \mathbf{5 2}(\mathbf{5 0} \%) \\
\text { integrate people with disabilities? }\end{array}$ & $8(5.8 \%)$ & $46(44.2 \%)$ \\
\hline
\end{tabular}

The less known policies, both from the internal-focus, were corporate policies that define commitment and company goals concerning labor inclusion of people with disabilities $(70.2 \%$ affirmed they did not know whether or not they were implemented), and the existence of a strategic plan to normalize disability in the business and working environment aimed at company stakeholders (81.7\% did not know).
Regarding the results of individual effectiveness, the participants stated that they identified with and felt affectively committed to the organization (Table 3). The majority of participants had not been absent from work for reasons other than the fact of having suffered an accident (77.9\%). Among those who took time off work, $11.5 \%$ were away for less than a whole working day.

Table 3. N, Minimum, maximum, mean and standard deviations of individual effectiveness variables.

\begin{tabular}{|c|c|c|c|c|c|}
\hline Dimension & $\mathrm{N}$ & Min & $\operatorname{Max}$ & Mean & $\mathrm{SD}$ \\
\hline IDENTIFICATION & 104 & 1.83 & 5.00 & 3.76 & .65 \\
\hline COMMITMENT & 104 & 1.25 & 4.75 & 3.68 & .62 \\
\hline Need commitment & 104 & 1.00 & 5.00 & 1.75 & .79 \\
\hline Exchange commitment & 104 & 1.00 & 5.00 & 3.51 & .77 \\
\hline Affective commitment & 104 & 1.50 & 5.00 & 3.65 & .68 \\
\hline Value commitment & 104 & 1.00 & 5.00 & 3.30 & .77 \\
\hline
\end{tabular}

Table 4 presents the correlations between the control, dependent and independent variables. Contrary to expectations, perceived deployment of external-focus policies did not correlate with any of the variables, except with the perceived deployment of internal-focus policies. Therefore, we removed external-focus policies perception from subsequent analysis. Likewise, absenteeism did not correlate with any independent variable so it was also eliminated from subsequent analysis.
The control variable tenure correlated negatively and significantly with the perception of deployment of internalfocus policies and positively with identification, exchange commitment, affective commitment and value commitment. This indicates an increase in the identification with and commitment to the organization over the years, and a decrease in perceived deployment of internal-focus policies. 
Table 4. Correlations

\begin{tabular}{|c|c|c|c|c|c|c|c|c|c|c|c|c|c|}
\hline & 1 & 2 & 3 & 4 & 5 & 6 & 7 & 8 & 9 & 10 & 11 & 12 & 13 \\
\hline \multicolumn{14}{|l|}{ Control variables } \\
\hline 1.Gendera: & - & & & & & & & & & & & & \\
\hline 2.Position ${ }^{\mathrm{b}}$ & -.140 & - & & & & & & & & & & & \\
\hline 3.Tenure & -.009 & $-.230 *$ & - & & & & & & & & & & \\
\hline 4.Importance of internal policies & -.159 & -.114 & .010 & - & & & & & & & & & \\
\hline 5.Importance of external policies & -.062 & $-.206^{*}$ & .056 & $.856^{* *}$ & - & & & & & & & & \\
\hline \multicolumn{14}{|l|}{ Independent variables } \\
\hline 6.Internal policies & -.090 & .000 & $-.199^{*}$ & .067 & .012 & - & & & & & & & \\
\hline 7.External policies & -.044 & -.100 & .052 & .067 & .115 & $.247^{*}$ & - & & & & & & \\
\hline \multicolumn{14}{|l|}{ Dependent variables } \\
\hline 8.Identification & -.022 & -.110 & $.232^{*}$ & -.034 & -.076 & $.233^{*}$ & 109 & - & & & & & \\
\hline \multicolumn{14}{|l|}{ Commitment } \\
\hline 9.Need c. & -.002 & .037 & -.044 & .036 & .054 & -.189 & -.112 & $-.686^{* *}$ & - & & & & \\
\hline 10.Exchange c. & -.053 & .044 & $.201 *$ & .004 & -.078 & .052 & .036 & $.551 * *$ & $-.587 * *$ & - & & & \\
\hline 11.Affective c. & -.071 & -.066 & $.245^{*}$ & .018 & -.064 & .108 & .014 & $.814^{* *}$ & $-.661^{* *}$ & $.514^{* *}$ & - & & \\
\hline 12.Values c. & .081 & -.063 & $.229^{*}$ & -.024 & -.015 & $.202^{*}$ & .113 & $.703^{* *}$ & $-.561^{* *}$ & $.509^{* *}$ & $.649^{* *}$ & - & \\
\hline 13. Absenteeismc ${ }^{c}$ & .013 & .141 & -.046 & -.171 & $-.205^{*}$ & -.040 & -.019 & .117 & -.063 & .157 &.-.052 & .05 & - \\
\hline
\end{tabular}
$* p<.05 ; * * p<.01$

a Dummy coded: female $=0$, male $=1$; ${ }^{b}$ Coded: $0=$ Manager, $1=$ Technical, $2=$ Specialist, $3=$ Non-qualified employee, $4=$ Other; ${ }^{c}$ Dummy coded: No=0, Yes $=1$

Based on these results, we ran some regression analyses of the relationship between employees' perceptions of the

deployment level of internal-focus policies and their commitment and identification (Table 5).

Table 5. Regression analysis of the relationship between employees' perceptions of internal and External-focus Policies and employees' commitment and identification. Note: Values reported are standardized regression coefficients.

\begin{tabular}{|c|c|c|c|c|c|c|c|c|c|c|}
\hline & $\begin{array}{c}\text { Controls } \\
\text { only }\end{array}$ & ID & $\begin{array}{c}\text { Controls } \\
\text { only }\end{array}$ & $\mathrm{NC}$ & $\begin{array}{c}\text { Controls } \\
\text { only }\end{array}$ & $\mathrm{EC}$ & $\begin{array}{c}\text { Controls } \\
\text { only }\end{array}$ & $\mathrm{AC}$ & $\begin{array}{c}\text { Controls } \\
\text { only }\end{array}$ & $\mathrm{VC}$ \\
\hline \multicolumn{11}{|l|}{ Control variables } \\
\hline Gender ${ }^{\mathrm{a}}$ & -.023 & -.001 & .002 & -.015 & -.019 & -.010 & -.051 & -.038 & .084 & .106 \\
\hline Position ${ }^{b}$ & -.094 & -.080 & .045 & .034 & .060 & .066 & -.053 & -.245 & -.005 & .010 \\
\hline Tenure & $.222 *$ & $.246^{*}$ & -.040 & -.058 & $.229 *$ & $.239 *$ & $.249 *$ & $.263^{* *}$ & $.231 *$ & $.255^{*}$ \\
\hline IP importance & .160 & .077 & -.056 & .007 & .276 & .242 & .301 & .253 & .026 & -.057 \\
\hline EP importance & -.246 & -.194 & .114 & .075 & -.315 & -.294 & -.350 & -.320 & -.046 & .006 \\
\hline \multicolumn{11}{|c|}{ Independent variables } \\
\hline IP perception & & $.252^{*}$ & & -.194 & & .103 & & .154 & & $.253 *$ \\
\hline Adjusted $\mathrm{R}^{2}$ & .028 & .135 & .087 & -.016 & .028 & .029 & .050 & .061 & .012 & .066 \\
\hline$\Delta \mathrm{R}^{2}$ & & .060 & & .035 & & .010 & & .019 & & .060 \\
\hline $\mathrm{F}$ & 1.6 & $2.58^{*}$ & .15 & .728 & 1.597 & 1.508 & 2.087 & 2.114 & 1.251 & $2.206^{*}$ \\
\hline
\end{tabular}

$* p<.05 ; * * p<.01 ;{ }^{\text {a }}$ Dummy coded: female $=0$, male $=1 ;{ }^{\mathrm{b}}$ Coded: $0=$ Manager, $1=$ Technical, $2=$ Specialist, $3=$ Non-qualified employee, $4=$ Other

Note: ID=Identification, $\mathrm{NC}=$ Need commitment, $\mathrm{EC}=$ Exchange commitment, $\mathrm{AC}=$ Affective commitment, $\mathrm{VC}=\mathrm{Value}$ commitment, $\mathrm{IP}=\mathrm{Internal}$ policies, $\mathrm{EP}=$ External policies

The first step included age, gender, position, tenure, and perceived importance of internal and external policies as control variables. The second step included the influence of employees' perceptions on their commitment and identification. The control-only models were not statistically significant, while the second model was significant in two cases (Identification and Value commitment). In both cases there exists a positive relationship with internal-focus policies. Figure 1 shows that employees with low deployment perception of internal policies (those who consider that none or one of the internal policies are deployed) have lower levels of identification and value commitment than those with high deployment perception of internal policies (those who consider that at least two of the internal policies are deployed).

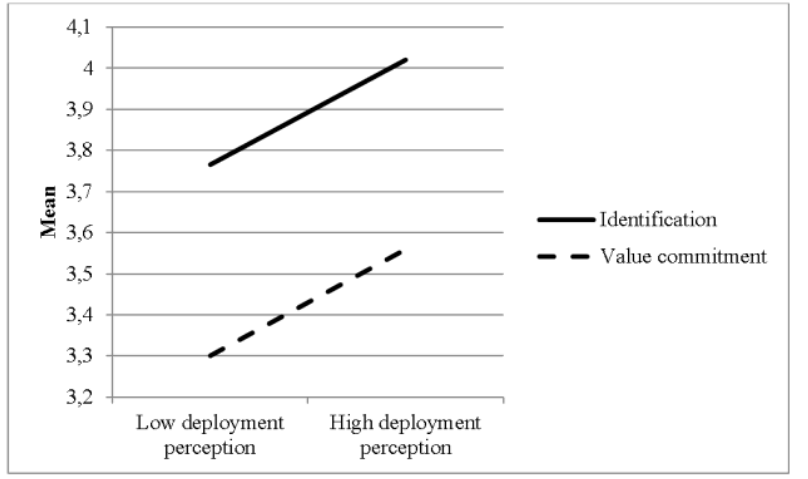

Figure 1. Relation between employees' perception of internal-focus policies deployment, identification and value commitment. 


\section{Discussion}

According to Spanish National Statistics Institute (Instituto Nacional de Estadística, INE, 2013), 35\% of people with disability is unemployed, while the general rate reaches $26.1 \%$. In this sense, it is important to facilitate the development of corporate social responsibility policies aimed at inclusion and addressing the needs of vulnerable groups such as people with disabilities. Nevertheless, it is interesting to note the limited number of studies that have analyzed the impact of these policies on employees (Rodrigo \& Arenas, 2008).

Corporate social responsibility policies deployment allows, on the one hand, an organization to comply with local, national and international regulations concerning the inclusion of people with disabilities in the productive sector and, on the other hand, helps the company build a socially responsible image, thus increasing its social acceptance (Galbreath, 2010).

Regarding results, it is interesting to point out that the high lack of knowledge by employees in relation to the degree of deployment of CSR policies. In this sense, other studies indicate that employees tend to perceive low levels of information on issues related to political and organizational strategies (Morsing, 2006). Policies with higher levels of knowledge by employees are the external focus. This result indicates that companies tend to prioritize marketing campaigns linked to their CSR policies (Chaudhri, 2014).

Concerning the impact of corporate social responsibility policies on employees, in this research we found that only the perception of internal-focus policies had an effect on their identification and commitment (especially value commitment), while the external-focus policies did not have any effect.

With regard to results for tenure, we observe that they correlated significantly with perceived deployment of internal-focus policies, indicating that a longer tenure generates lower deployment perception of internal policies. This result can be partially explained by the correlation between tenure and position, given that longer tenure is linked to higher position levels and affective commitment (Natarajan \& Nagar, 2011). In this sense, our results could be showing a greater awareness and criticism about the policies and strategies developed by the organization.

\section{References}

Aguinis, H., \& Glavas, A. (2012). What we know and don't know about corporate social responsibility: A review and research agenda. Journal of Management, 1, 1-37. doi: 10.1177/0149206311436079

Aharon, T., Lior, O., Yaki, B., \& Gal, K. (2011). Corporate social responsibility, organizational justice and job satisfaction: How do they interrelate, if at all? Revista de Psicología del Trabajo y de las Organizaciones, 27(1), 67-72. doi: 10.5093/tr2011v27n1a7

Al-bdour, A., Nasruddin, E., \& Lin, S. (2010). The relationship between internal corporate social responsibility and organizational commitment within the banking sector in Jordan. International Journal of Human and
No significant relationships were found between the perceptions of employees and absenteeism rates, contrary to our expectations. In the current context of crisis, the Spanish National Statistics Institute (Instituto Nacional de Estadística, INE) points out a slight decrease in absenteeism rates since 2009, after a period of steady growth since 2005. This circumstantial fact may justify the low absenteeism rates uncovered by our research, which may also have contributed to the lack of significant results.

It would be very interesting in future research to examine the results found regarding the key role that internal-focus policies play in employees' identification and commitment in different organizations and sectors. Specifically, we plan to analyze whether those sectors that have been more deeply affected by the crisis present different results to those in this study. On the other hand, this study is focused on employees' perceptions. It would be interesting to analyze deeply the employees' knowledge about their companies CSR policies.

Finally, organizations "should contribute to ensuring that men and women with disabilities are accorded dignity, autonomy and full participation in society. The principle of non-discrimination should be respected, and organizations should consider making reasonable provisions for access to facilities" (International Organization for Standardization, ISO, 2010, p. 29). However, the difficulties of labor inclusion of this target-group are still evident. In this regard, we consider, to quote Munduate, Di Marco, Martínez-Corts, Arenas, \& Gamero, 2013), that "the integration of disabled people at work needs to be understood as a standardized process that seeks the ultimate goal of promoting employment under the same conditions as other workers" (p. 125).

The results obtained from this research are promising and represent a first step towards further study of the role played by policies oriented to inclusion of people with disabilities in organizational and work contexts. Our research highlights the impact of internal-focus policies for the inclusion of people with disabilities in the commitment and identification of all employees, those with and without disabilities. In this sense, we believe it is necessary to further develop strategic internal policies committed to inclusion and equality opportunities, in order to achieve the double objective: to increase identification and commitment and to enhance labor inclusion of people with disabilities.

Social Sciences, 5(14), 932-951. Retrieved from http://www.waset.org/publications/1224

Alcover de la Hera, C. M., \& Pérez Torres, V. (2011). Trabajadores con discapacidad: problemas, retos y principios de actuación en salud ocupacional. Medicina y Seguridad del Trabajo, 57, 206-223. doi: 10.4321/S0465546X2011000500013

Ali, I., Rehman, K., Ali, S., Yousaf, J., \& Zia, M. (2010). Corporate social responsibility influences, employee commitment and organizational performance. African Journal of Business Management, 4(12), 2796-2801. Retrieved from http://www.academicjournals.org/AJBM 
Birth, G., Illia, L., Lurati, F., \& Zamparini, A. (2008). Communicating CSR: practices among Switzerland's top 300 companies. Corporate Communications: An International Journal, 13(2), 182-196. doi: 10.1108/13563280810869604

Brammer, S., Millington, A., \& Rayton, B. (2007). The contribution of corporate social responsibility to organizational commitment. The International Journal of Human Resource Management, 18, 1701-1719. doi: 10.1080/09585190701570866

Branco, M. C., \& Rodrigues, L. L. (2006). Corporate social responsibility and resource-based perspectives. Journal of Business Ethics, 69(2), 111132. doi: 10.1007/s10551-006-9071-z

Campbell, J. P. (1977). On the nature of organizational effectiveness. In P. S. Goodman, \& J. M. Pennings, New perspectives on organizational effectiveness (pp. 13-55). London: Jossey-Bass Publishers.

Chaudhri, V. (2014). Corporate Social Responsibility and the communication imperative perspectives from CSR managers. International Journal of Business Communication, First online, 1-24.

Dahlsrud, A. (2008). How corporate social responsibility is defined: An analysis of 37 definitions. Corporate Social Responsibility and Environmental Management, 13, 1-13. doi: 10.1002/csr.132

David, F. R. (2010). Strategic Management: Concepts (13th ed). Englewood Cliffs, NJ: Prentice Hall.

Ernst\&Young \& Biocat. (2011). Catalonia Life Sciences Report 2011. Retrieved from http://www.biocat.cat/sites/default/files/Catalonia_Life_Sciences Report final.pdf

European Commission. (2001). Green Paper - Promoting a European framework for Corporate Social Responsibility. Brussels: European Commission. Retrieved from http://europa.eu/rapid/press-release_DOC-01-9_en.pdf

European Commission. (2011). A renewed EU strategy 2011-14 for Corporate Social Responsibility. Brussels: European Commission. Retrieved from http://eur-lex.europa.eu/legalcontent/EN/TXT/?uri=celex:52011DC0681

Galbreath, J. (2010). How does corporate social responsibility benefit firms? Evidence from Australia. European Business Review, 22(4), 411-431. doi: 10.1108/09555341011056186

Instituto Nacional de Estadística, INE. (2013). Encuesta de población activa. Retrieved from http://www.ine.es/prensa/epa_tabla.htm

International Labour Office, ILO. (2010). Disability in the Workplace: Company Practices. Geneva: ILO. Retrieved from http://www.ilo.org/public/english/dialogue/actemp/downloads/publ ications/working_paper_n3.pdf

International Organization for Standardization, ISO. (2010). ISO 26000:2010. Guidance on Social Responsibility. Genève: ISO

Kim, H., Lee, M., Lee, H., \& Kim, N. (2010). Corporate social responsibility and employee-company identification. Journal of Business Ethics, 95, 557-569. doi:10.1007/s10551-010-0440-2

Morsing, M. (2006). Corporate social responsibility as strategic autocommunication: On the role of external stakeholders for member identification. Business Ethics: A European Review, 15, 171-182. doi: 10.1111/j.1467-8608.2006.00440.x

Munduate, L., Di Marco, D., Martínez-Corts, I., Arenas, A., \& Gamero, N. (2013). Rebuilding the social dialogue and promoting inclusive organizations. A tool for social innovation in times of crisis. Papeles del Psicólogo, 35(2), 122-129. Retrieved from http://www.papelesdelpsicologo.es/english/2363.pdf

National Disability Coordination Officer Program. (nd). Value for business. Queensland: NDCOP.
Natarajan, N. K., \& Nagar, D. (2011). Effects of service tenure and nature of occupation on organizational commitment and job satisfaction. Journal of Management Research, 11(1), 59-64.

Pinillos, A. A. Una herramienta de competitividad para el futuro [CSR 2.0. A tool of competitiveness for the future]. Telos, 79, 100-111. Retrieved from http://www.albertoandreu.com/wp-content/uploads/2011/02/

TELOS_Andreu_RSC_20_espa\%C3\%B1ol.pdf

Podsakoff, P. M., MacKenzie, S. B., Lee, J. Y., \& Podsakoff, N. P. (2003). Common method biases in behavioral research: a critical review of the literature and recommended remedies. Journal of Applied Psychology, 88(5), 879-903. doi: 10.1037/0021-9010.88.5.879

Quijano, S., Navarro, J., \& Cornejo, J. M. (2000). Un modelo integrado de compromiso e identificación con la organización: análisis del cuestionario ASH-ICI [An integrated model of organizational commitment and identification: analysis of the HSA-ICI questionnaire]. Revista de Psicologia Social Aplicada, 10(2), 27-61

Quijano, S. D., Navarro, J., Yepes, M., Berger, R., \& Romeo, M. (2008). Human System Audit (HSA) for the analysis of human behaviour in organizations. Papeles del Psicólogo, 29(1), 92-106.

Real Decreto Legislativo 1/2013, de 29 de noviembre por el que se aprueba el Texto Refundido de la Ley General de derechos de las personas con discapacidad y de su inclusión social (29 de Noviembre de 2013). Retrieved from https://www.boe.es/boe/dias/2013/12/03/pdfs/BOEA-2013-12632.pdf

Rodrigo, P., \& Arenas, D. (2008). Do employees care about CSR programs? A typology of employees according to their attitudes. Journal of Business Ethics, 83, 265-283. doi: 10.1007/s10551-007-9618-7

Romeo, M., Yepes, M., Berger, R., Guàrdia, J., \& Castro, C. (2011). Identification-commitment inventory (ICI model): confirmatory factor analysis and construct validity. Quality \& Quantity, 45(4), 901-909. doi:10.1007/s11135-010-9402-0

Romeo, M., Berger, R., Yepes-Baldó, M., \& Guardia-Olmos, J. (2011). Validez del Cuestionario de Identificación y Compromiso (HSA-ICI). Escritos de Psicología / Psychological Writings, 4(1), 1-8. doi:10.5231/psy.writ.2011.0803

Skudiene, V., \& Auruskeviciene, V. (2012). The contribution of corporate social responsability to internal employee motivation. Baltic Journal of Management, 7(1), 49-67. doi: 10.1108/17465261211197421

Turker, D. (2009). How corporate and social responsibility influences organizational commitment. Journal of Business Ethics, 89(2), 189-204. doi: $10.1007 /$ s10551-008-9993-8

Villafañe, J. (2009). Reputación corporativa y RSC. Bases empíricas para un análisis [Corporate reputation and CSR. Empirical bases for analysis]. Telos, 79, 75-81. Retrieved from http://telos.fundaciontelefonica.com/ telos/articulocuaderno.asp@idarticulo=3\&rev=79.htm

Vitaliano, D. (2010). Corporate social responsibility and labor turnover. Corporate Governance, 10, 563-573. doi: 10.1108/14720701011085544

Wang, H., Tong, L., Takeuchi, R., \& George, G. (2016). Corporate Social Responsibility: An overview and new research directions. Academy of Management Journal, 59(2), 534-544. doi: 10.5465/amj.2016.5001

Wiggett-Barnard, C., \& Swartz, L. (2012). What facilitates the entry of persons with disabilities into South African companies?. Disability and Rehabilitation, 34(12), 1016-1023. doi: 10.3109/09638288.2011.631679

(Article received: 14-09-2015; revised: 09-09-2016; accepted: 15-09-2016) 